\section{Nauplius}

The Journal OF The Brazilian Crustacean Society

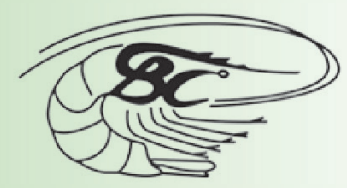

e-ISSN 2358-2936

www.scielo.br/nau www.crustacea.org.br
This article is part of the special series

offered by the Brazilian Crustacean Society

in honor to Nilton José Hebling in recognition

of his dedication and contributions to the development of carcinology in Brazil.

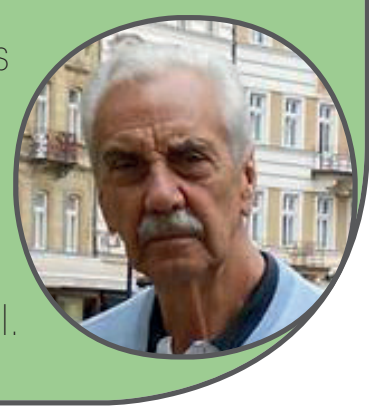

Original Article

\title{
Abbreviated larval development of Macrobrachium inpa Kensley and Walker, 1982 (Crustacea: Decapoda: Palaemonidae) from an Amazon Basin forest stream, Brazil, reared in the laboratory
}

\author{
Célio Magalhães
}

Instituto Nacional de Pesquisas da Amazônia. Av. André Araújo, 2936, 69067-375

Manaus, Amazonas, Brazil. E-mail: celiomag@inpa.gov.br

ZOOBANK http://zoobank.org/urn:lsid:zoobank.org:pub:1FE8E095-5586-4A09BD42-91ED8BB53DF8

\section{ABSTRACT}

This paper brings the description and illustrations of the abbreviated larval development of the Amazonian freshwater palaemonid shrimp, Macrobrachium inpa Kensley and Walker, 1982. The study was based on ovigerous females (mean total body length of $27.0 \pm 1.64 \mathrm{~mm}$ ) collected in a small forest stream in the Reserva Florestal Ducke, near Manaus, Brazil, of which four released their larvae in the laboratory. The females carried 8 to 19 eliptical $(2.39 \pm 0.10 \times 1.67 \pm 0.08 \mathrm{~mm})$, yolk-rich eggs. The larval period consists of three benthic, lecithotrophic larval stages, and lasts 10-11 days. The newly-hatched larvae bear very advanced morphological features such as antenna with several marginal plumose seta on scaphocerite and long, multiarticulated flagellum; fully developed, functional uniramous pereiopods 3-5 (walking legs) and biramous pleopods. The morphology of the carapace, all appendages of the cephalothorax and pleon, and the tail fan are described in detail and illustrated. The larval form was considered to be a decapodid because of the benthic behavior and due to the fact that functional walking legs and pleopods are the main structures for displacement and propulsion. The larval development of $M$. inpa is compared with those of the so-called "continental" group of the caridean shrimps from the Amazon River basin. 


\section{KEY WORDS}

Caridea, freshwater shrimp, morphology, freshwaterization, Rio Negro basin.

\section{INTRODUCTION}

The freshwater palaemonid shrimp Macrobrachium inpa Kensley and Walker, 1982 is so far known from some tributaries of the lower Rio Negro basin, in the state of Amazonas, Brazil, where it occurs in small, shadowed forest streams with very acidic, plankton-poor black waters (Kensley and Walker, 1982; Magalhães, 2009). The specimens usually inhabit the submerged leaf litter or can be found in holes and fissures of submerged logs and branches (Walker and Ferreira, 1985).

The species is poorly studied. Besides the taxonomic description, Kensley and Walker (1982) added information on feeding ecology, Walker and Ferreira (1985) studied the reproductive biology and population dynamics, and Gualberto et al. (2012) investigated the population structure, fecundity and ecological aspects of a population from an urban forest fragment in the city of Manaus. The species has an abbreviated larval development, and Magalhães and Walker (1988) offered a brief description of its first larval stage. A similar type of larval development has been verified in other Amazonian species, such as Macrobrachium nattereri (Heller, 1862) (see Magalhães, 1989), M. jelskii (Miers, 1877) (see Magalhães, 2000), Palaemon ivonicus (Holthuis, 1950) (see Magalhães, 1986), Pseudopalaemon chryseus Kensley and Walker, 1982 (see Magalhães, 1986/87), and Pseudopalaemon amazonensis Ramos-Porto, 1979 (see Magalhães and Medeiros, 1998). Descriptions of the abbreviated larval development of other Neotropical species of Macrobrachium Spence Bate, 1868 were published by Müller (1892), Bueno and Rodrigues (1995), Pereira and García (1995), Graça Melo and Brossi-Garcia (1999), Signoret et al. (2000) and Alvarez et al. (2002). Many other freshwater palaemonid species worldwide are known or inferred to have such type of development (see citations in Jalihal et al., 1993; Pereira and García, 1995).

In addition to $M$. inpa, at least three other taxa pertaining to the continental species of Macrobrachium with short rostrum are distributed in the lower Rio Negro basin (Kensley and Walker, 1982; Magalhães and Pereira, 2007): Macrobrachium brasiliense (Heller,
1862), Macrobrachium ferreirai Kensley and Walker, 1982, and Macrobrachium nattereri. All four are very similar and phylogenetically closely related (Pileggi and Mantelatto, 2010). The study of their larval development can add new characters, thus contributing to the study of the taxonomy and systematics of this group. The purpose of this paper is to provide morphological descriptions and illustrations of the three larval and first juvenile stages of $M$. inpa reared in the laboratory.

\section{Material And Methods}

Some ovigerous females of Macrobrachium inpa were collected using dip net in the igarapé (an upland forest stream) Barro Branco, in the Reserva Florestal Ducke $\left(2^{\circ} 55^{\prime} 48^{\prime \prime} \mathrm{S} 59^{\circ} 58^{\prime} 28^{\prime \prime} \mathrm{W}\right)$, near Manaus, in the state of Amazonas, in May and June 1994. The females were transported to the laboratory in a plastic container and kept in a $680 \times 300 \times 400 \mathrm{~mm}$ aquarium with some pieces of brick for shelter. Only four females carrying eggs with advanced embryos hatched their larvae and at least five specimens of each stage were used for observations and illustrations. Usually, two larvae of the first female to release its clutch were use for preparing the illustrations; at least one larva of the remainder females was used to verify any variability. Line drawings of the whole specimen in dorsal view were made with the aid of a stereoscopic microscope (Wild M8) equipped with a drawing tube and a light microscope (Leitz Laborlux S) with drawing tube was used for the line drawing of the dissected parts. Line drawings were scanned at 600 dpi and edited in Adobe Photoshop CS 2 software at $1200 \mathrm{dpi}$. The plates were mounted in CorelDraw X3 software. The procedures for larval rearing and for taking measurements, dissections, preparing the line drawings, and morphological descriptions were made according to Magalhães (2000). The first larval stage is described in detail and only marked differences are mentioned in the morphological description of the respective structure in subsequent stages. The temperature of the water used for larval rearing ranged from 26 to $28^{\circ} \mathrm{C}$. The four female specimens used in this study are deposited in the Crustacean Collection 
of the Instituto Nacional de Pesquisas da Amazônia (Manaus) under the catalogue number INPA 686.

\section{RESULTS}

Ovigerous females with a mean total body length of $27.0 \pm 1.64 \mathrm{~mm}(\mathrm{n}=11)$ carried 8 to 19 eliptical, yolkrich, dark red eggs measuring $2.39 \pm 0.10 \mathrm{~mm}$ (long axis) and $1.67 \pm 0.08 \mathrm{~mm}$ (short axis) $(\mathrm{n}=44 ; 4$ eggs randomly chosen from each of these 11 non hatching females were measured). It took two to three days for the females to release their entire clutch. Hatching was never observed during daytime. The species goes through three benthic larval stages without feeding. The duration of the whole larval period was ten to eleven days.

First larval stage (Decapodid I): mean total length $=6.01 \pm 0.11 \mathrm{~mm} ; \mathrm{n}=5$; duration: $1-2$ days (Figs. $1-17)$.

Cephalothorax (Figs. 1-2). Eyes sessile. Rostrum very short, unarmed, slightly overreaching anterior border of eyes, strongly curved downwards. Carapace with 1 small spine (antennal spine) always present on the anterolateral border, sometimes a minute spine present just ventrally to the antennal spine.

Antennule (Fig. 3) uniramous. Peduncle unsegmented. Inner flagellum simple, setaceous; setae denser along inner border, tipped with 1 simple seta; outer flagellum broader than and nearly as long as inner one, tipped with 2 aesthetes, 1 large and 2 minute setae.

Antenna (Fig. 4) biramous. Protopod bisegmented; coxa with small epipod ventrally at inner side of distal margin; basis with subtriangular spine on disto-ventral margin. Scaphocerite (exopod scale) unsegmented, long, overreaching the end of the antennular peduncle, bearing 24-25 plumose setae along inner and distal margins, and short spine on disto-lateral corner. Endopod as a long, multi-articulated flagellum about 4-5 times as long as the scaphocerite; first and second segments bearing, respectively, 2-3 small plumose setae, remainder segments usually with $2-4$ subdistal or distal simple setae and distal segment with 5 subdistal and distal simple seta.

Mandibles (Fig. 5) rudimentary, lacking palp. Left and right mandibles alike, distinct cleft between incisor and molar processes. Incisor process with 1 sharp tooth and 1-2 incipient denticles subterminally; molar process smooth, stouter than incisor one.

Maxillule (Fig. 6) uniramous, rudimentary. Coxal and basial endites with some distal and subdistal protuberances. Endopod slightly bilobed, bearing minute spine distally on proximal lobe.

Maxilla (Fig. 7) biramous. Protopod rudimentary, bilobed, both endites with few distal protuberances. Endopod (palp) unsegmented, smooth. Scaphognathite (exopod) large, fringed with 30-32 marginal plumose setae.

Maxilliped 1 (Fig. 8) biramous. Protopod unsegmented, with subtriangular epipod and inner margin slightly bilobed, with small marginal protuberances. Endopod short, with minute spine subterminally. Exopod unsegmented, approximately 4 times longer than endopod, bearing 4 apical plumose setae; proximal outer border distinctly bulged, bearing 5 marginal plumose setae.

Maxilliped 2 (Fig. 9) biramous. Protopod unsegmented, with small, slightly bilobed epipod. Endopod rudimentary, strongly curved inwards, segmentations not clear or incipient. Exopod longer than endopod, with 3 long and 1 short apical plumose setae.

Maxilliped 3 (Fig. 10) biramous. Protopod bisegmented, smooth; coxa with outer margin somewhat bulged. Endopod slightly curved inwards, only segmentations between first and second, and between second and third segments distinct; distal segment bearing short, weakly plumose seta. Exopod shorter than endopod, bearing 2 subapical, simple short setae and 4 apical, long plumose setae.

Pereiopods 1 (Fig. 11) - 2 (Fig. 12) uniramous, partially developed, chelate buds, not functional, kept under ventral surface of cephalothorax; only segmentation between basis and endopod distinct. Both pereiopods approximately the same size.

Pereiopods 3, 4, 5 (Fig. 13) all similar, uniramous, well developed, fully functional. Coxa naked; basis with 3 simple setae on inner margin. Endopod 5-segmented, dactylus with short apical spine, several short, simple and/or weakly plumose setae scattered along segments, most of them in the propodus.

Pleon (Fig. 1) 6-segmented, smooth, all pleonites well distinct but segmentation between 6th somite and telson incomplete.

Pleopods 1 (Fig. 14), 2, 3 (Fig. 15), 4, 5 (Fig. 16) 

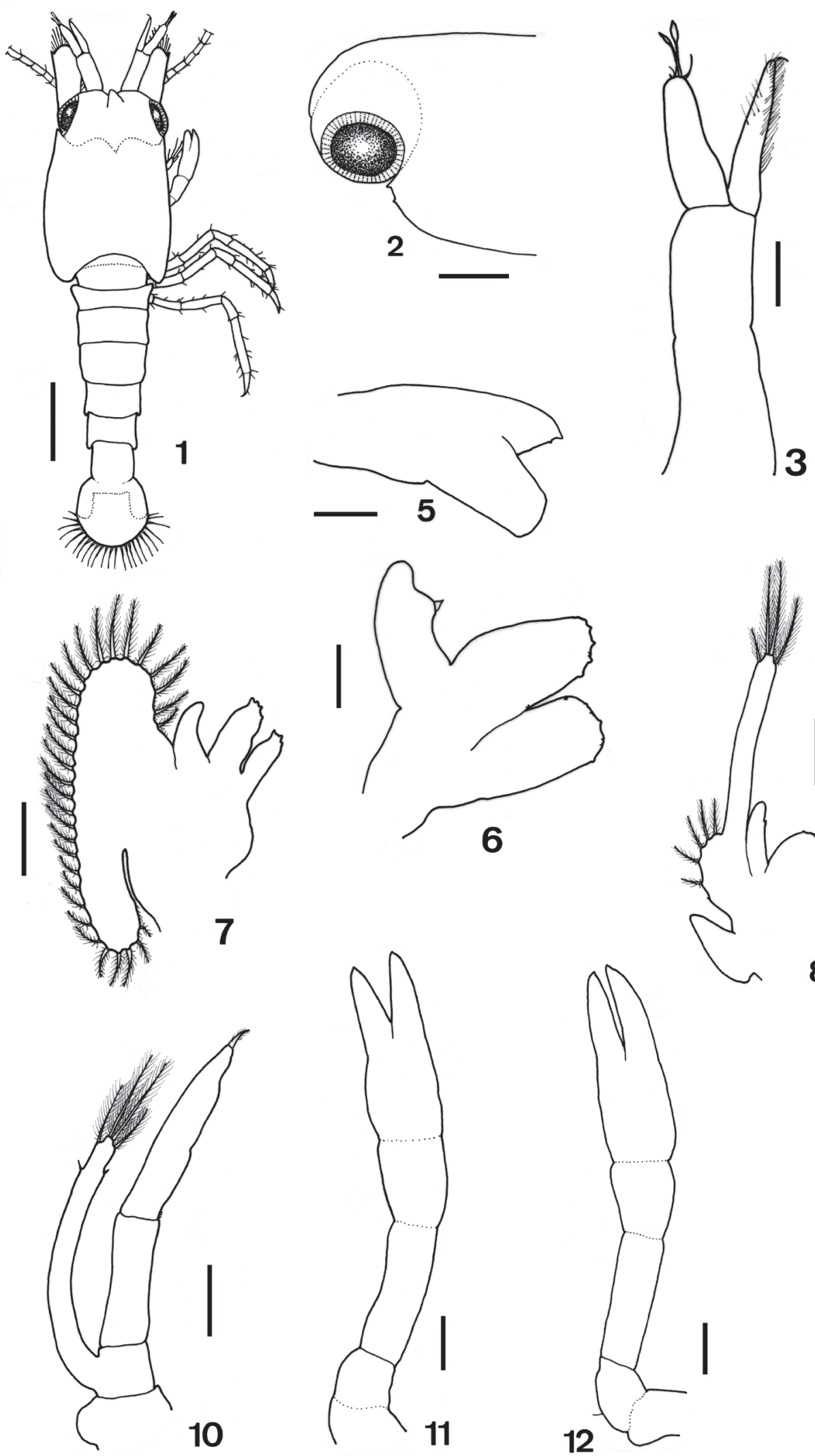

8
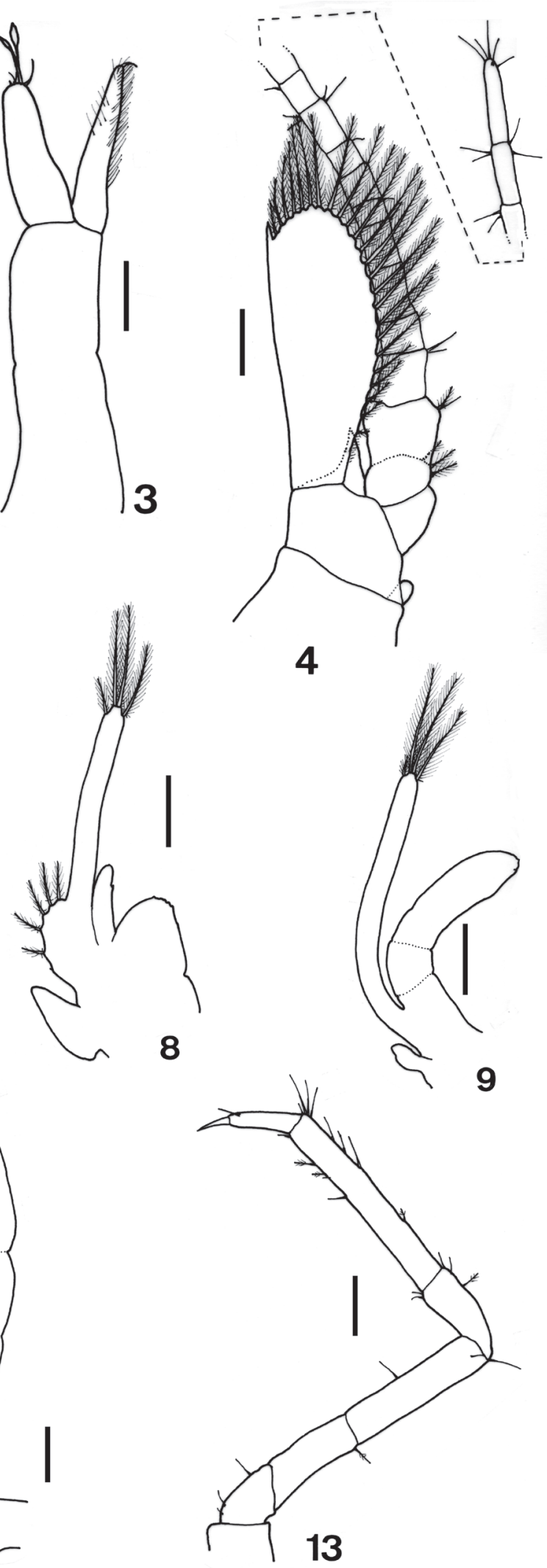

Figures 1-13. Macrobrachium inpa Kensley and Walker, 1982, first larval stage. 1, Dorsal view (left thoracic appendages not represented); 2, Lateral view of the anterior region of the carapace; 3, Antennule; 4, Antenna; 5, Mandible; 6, Maxillule; 7, Maxilla; 8, Maxilliped 1; 9, Maxilliped 2; 10, Maxilliped 3; 11, Pereiopod 1; 12, Pereiopod 2; 13, Pereiopod 5. (Scale bars: $1=1 \mathrm{~mm} ; 2=0.5$ $\mathrm{mm} ; 3,4,7-13=0.2 \mathrm{~mm} ; 5,6=0.1 \mathrm{~mm})$. 

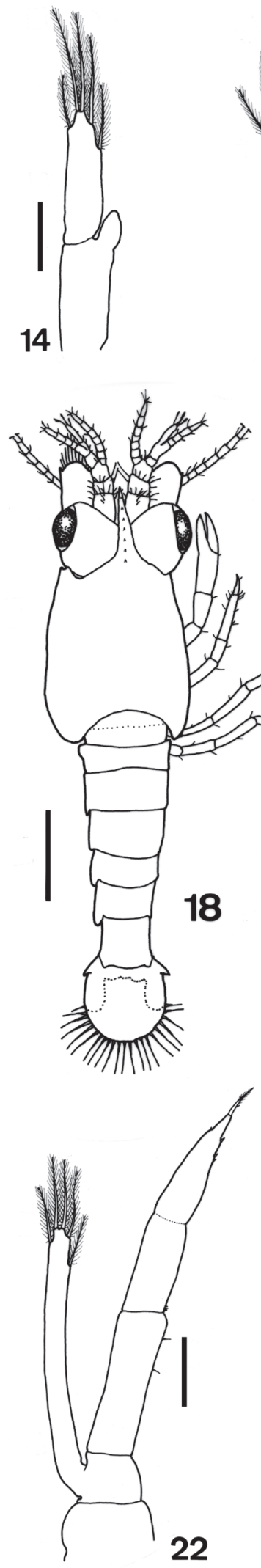

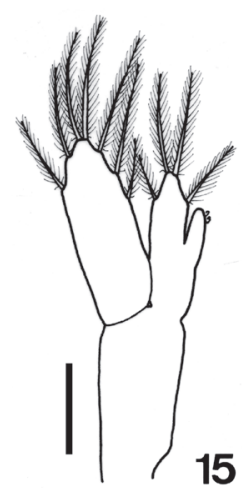

15

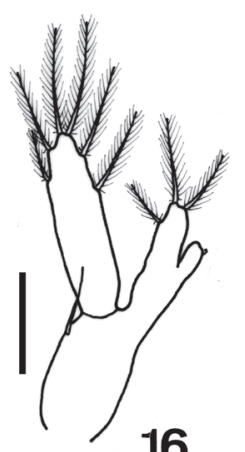

16
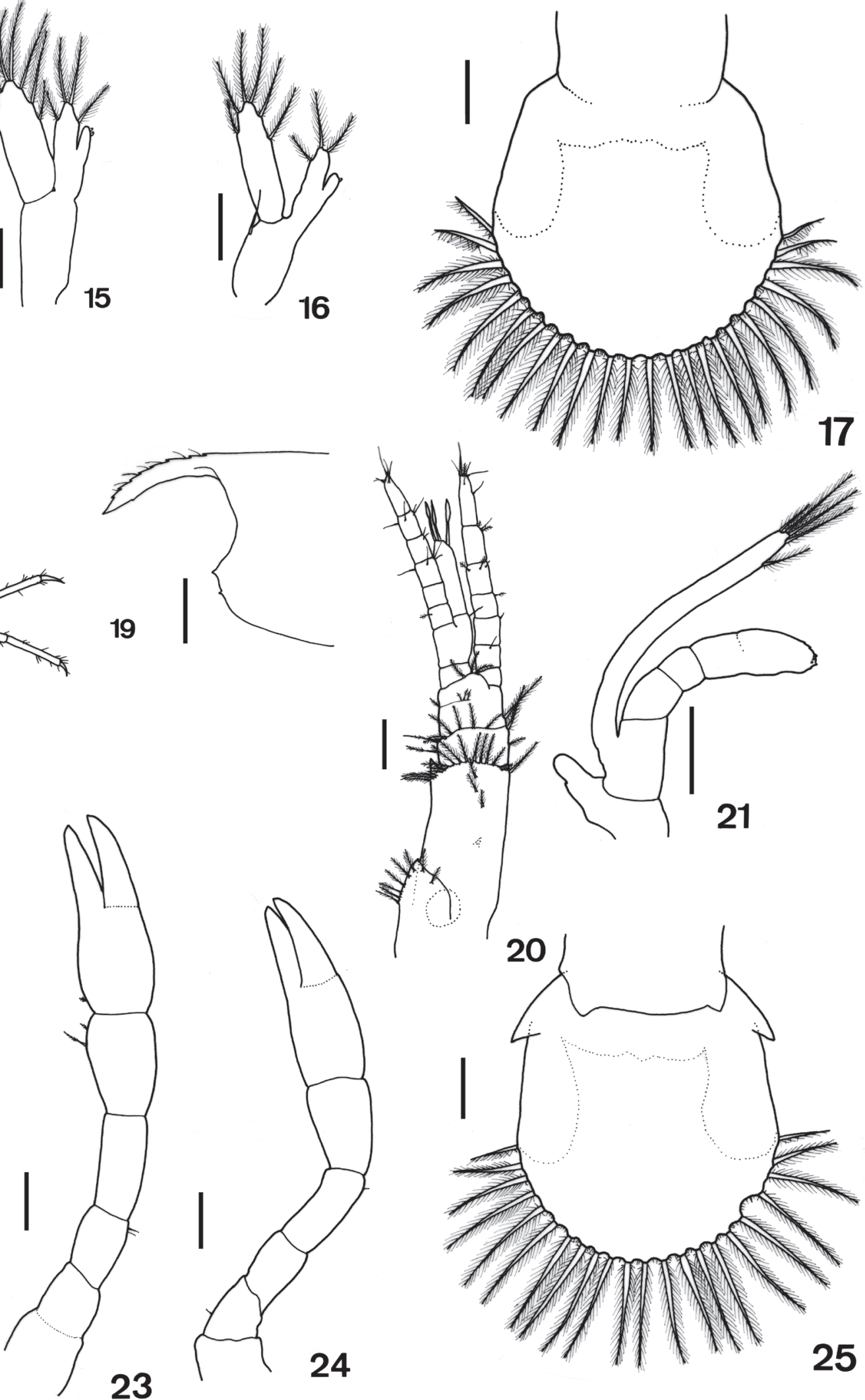

Figures 14-25. Macrobrachium inpa Kensley and Walker, 1982, first larval stage. 14, Pleopod 1; 15, Pleopod 2; 16, Pleopod 5; 17, Telson. Macrobrachium inpa, second larval stage. 18, Dorsal view (left thoracic appendages not represented); 19, Lateral view of the anterior region of the carapace; 20, Antennule; 21, Maxilliped 2; 22, Maxilliped 3; 23, Pereiopod 1; 24, Pereiopod 2; 25, Telson. (Scale bars: $18=1 \mathrm{~mm} ; 19=0.5 \mathrm{~mm} ; 20-25=0.2 \mathrm{~mm}$ ). 
biramous, well developed, fully functional. Protopod unsegmented. Endopod and exopod bearing several marginal plumose setae, except for the smooth endopod of pleopod 1. Appendices internae of pleopods 2-5 present, bearing cincinnuli.

Uropods (Fig. 17) absent; buds visible through telsonic cuticle.

Telson (Fig. 17) broad, flat, fan-like; posterior margin broadly convex, with $12+12$ plumose setae ( 2 outermost pairs plumose only on inner side).

Second larval stage (Decapodid II): mean total length $=6.16 \pm 0.12 \mathrm{~mm} ; \mathrm{n}=5$; duration: not measured (Figs. 18-25).

Cephalothorax (Figs. 18-19). Eyes stalked. Rostrum short, tip reaching distal margin of first segment of antennular peduncle, slightly curved downwards, rostral formula: $7-8 / 0-1$; space between dorsal teeth with short plumose seta.

Antennule (Fig. 20) 3-segmented, bearing several, short and long, plumose setae as illustrated. Proximal segment longest, with small ventral spine, subtriangular stylocerite (statocysts absent) and distal spine on the outer corner. Medial segment shortest. Distal segment with 3 short, plumose setae on antennular lobe. Inner flagellum 7-segmented, nearly as long as outer one. Outer flagellum subdivided after second segment; inner ramus shorter, unsegmented, bearing 3 apical slender aesthetes; outer ramus 6-segmented. Both flagella bearing small setae along segments.

Maxilliped 2 (Fig. 21). Protopod segmented, epipod larger than that of the first larval stage. Endopod still rudimentary, segmentations distinct, except for incomplete segmentation between penultimate and ultimate segments.

Maxilliped 3 (Fig. 22) with exopod bearing 5 plumose setae subdistally and distally.

Pereiopods 1 (Fig. 23) - 2 (Fig. 24) still not functional. All joints with distinct segmentation, except for the one between coxa and basis of pereiopod 1 . Pereiopod 1 slightly longer than pereiopod 2.

Pleon (Fig. 18) with segmentation between 6th pleonite and telson distinct.

Uropods (Fig. 25) only with posterior projection of protopod free, overreaching dorsally the proximal lateral margin of telson.
Third larval stage (Decapodid III): mean total length $=6.38 \pm 0.21 \mathrm{~mm} ; \mathrm{n}=5$; duration: not measured (Figs. 26-35).

Cephalothorax (Figs. 26-27). Tip of rostrum reaching distal margin of medial segment of antennular peduncle, rostral formula: 7-8/1. Carapace with antennal spine more conspicuous than in preceding stage.

Antennule (Fig. 28) similar to preceding stage, except for inner ramus of outer flagellum 2-segmented.

Antenna with 29 marginal plumose setae; otherwise similar to preceding stage.

Mandibles with cleft between incisor and molar processes more expanded; incisor process bearing 3 sharp teeth; molar process still rudimentary, but bearing 1 sharp tooth and some denticles.

Maxillule (Fig. 29) more developed than in preceding stage, with coxal endite bearing some minute, small and large, simple setae terminally and subterminally; basial endite bearing 3 simple setae subterminally, several protuberances terminally and subterminally.

Maxilla with endopod bearing 2 weakly plumose, short setae subterminally; otherwise similar to preceding stage.

Maxilliped 1 (Fig. 30) more developed than in preceding stage. Protopod with bilobed epipod; coxal endite with 4 short, simple setae, and 1 large, weakly plumose seta; basial endite with several, rudimentary, short and long, setae along inner and distal margins, and 2 median setae on the ventral surface (not illustrated). Endopod with large plumose setae subterminally. Exopod with proximal outer margin bearing 6-7 marginal plumose setae.

Maxilliped 2 (Fig. 31). Coxa bearing 3 simple setae subdistally on inner margin, and large bilobed epipod. Endopod strongly curved inwards, 4-segmented, segmentations clearly distinct; penultimate and ultimate segments much broader than first and second ones; penultimate segment with 2 rudimentary simple setae subterminally on outer margin, 1 subterminally on inner margin; last segment with several short, simple and serrated setae terminally and subterminally along distal margin.

Maxilliped 3 (Fig. 32). Coxa bearing 1 simple seta subterminally on inner margin. Endopod only with three clearly distinct segments, bearing 10, 5 , 


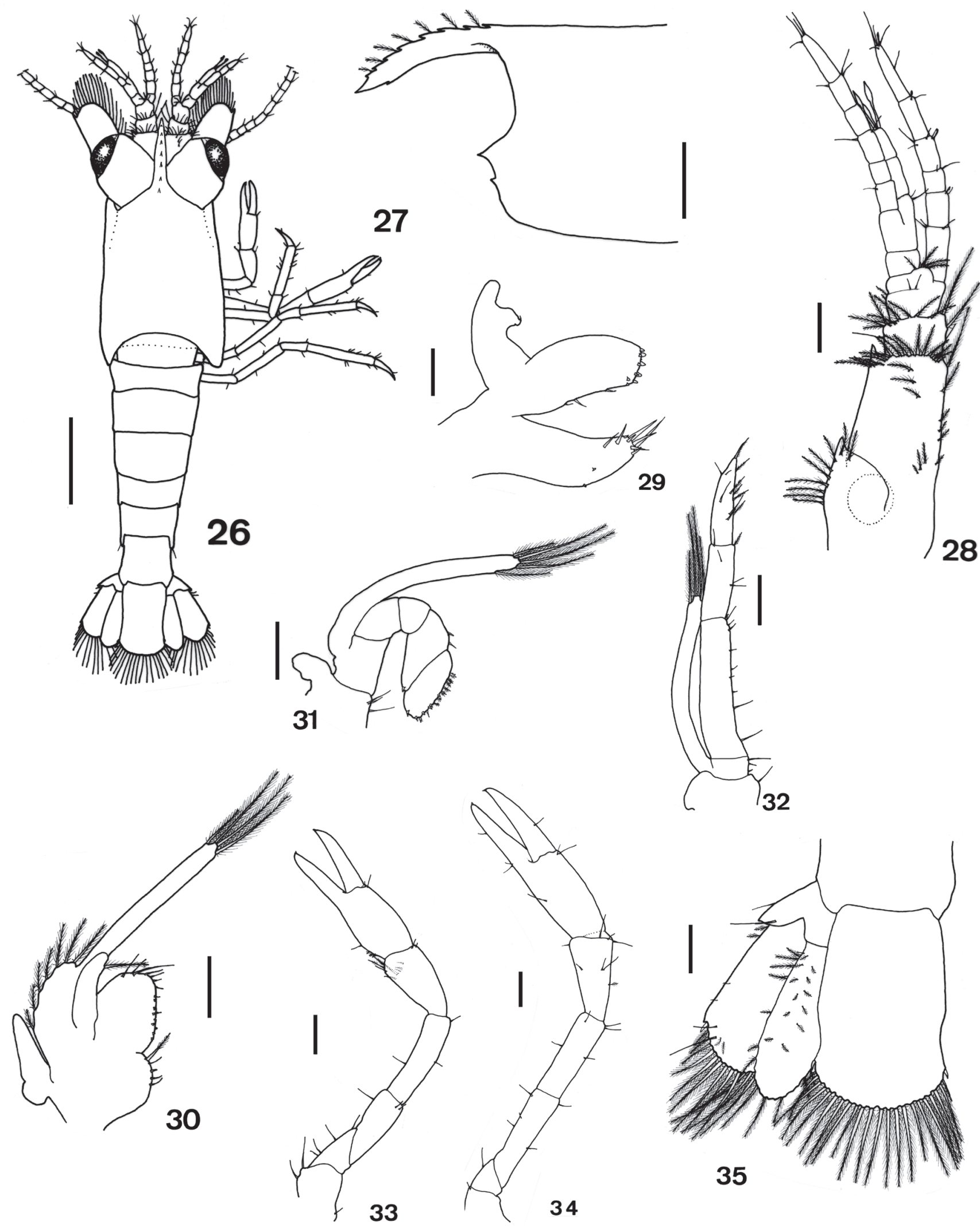

Figures 26-35. Macrobrachium inpa Kensley and Walker, 1982, third larval stage. 26, Dorsal view (left thoracic appendages not represented); 27, Lateral view of the anterior region of the carapace; 28, Antennule; 29, Maxillule; 30, Maxilliped 1; 31, Maxilliped 2; 32, Maxilliped 2; 33, Pereiopod 1; 34, Pereiopod 2; 35, Left uropod and telson. (Scale bars: $26=1 \mathrm{~mm} ; 27=0.5 \mathrm{~mm} ; 28,30-35$ $=0.2 \mathrm{~mm} ; 29=0.1 \mathrm{~mm})$. 
11 , simple and weakly plumose, short and long, setae from proximal to distal segment; distal segment with apical weakly plumose seta. Exopod about half as long as endopod, bearing 5 long, plumose setae terminally and subterminally.

Pereiopods 1 (Fig. 33) - 2 (Fig. 34) with chela still not functional; some simple setae scattered from coxa to dactylus. Pereiopod 1 with distinct subdistal row of 5 weakly plumose setae on inner margin of carpus.

Uropods (Fig. 35) totally free, functional. Protopod with outer distal corner acute, bearing 2 simple setae subterminally. Exopod fully developed, with 1 distolateral spine, 21-23 long, plumose setae along inner and distal margins, 2 short, weakly plumose setae proximally plus 2 short, simple setae on distal third of outer margin, and 2 short, weakly plumose plus 2 long, simple setae subterminally on dorsal surface. Endopod partially developed, with several short, weakly plumose setae scattered along outer margin and dorsal surface.

Telson (Fig. 35) subrectangular, narrower and longer than in preceding stage; lateral margins with distinct concavity on distal third on its length; distal margin strongly convex, bearing $11+11$ plumose setae and 1 pair of small spine on laterodistal corner.

First juvenile stage: mean total length $=6.54 \pm$ $0.23 \mathrm{~mm} ; \mathrm{n}=7$ (Figs. 36-47).

Cephalothorax (Figs. 36-37). Tip of rostrum slightly overreaching distal margin of medial segment of antennular peduncle, rostral formula: 7-8/1.

Antennule (Fig. 38) with statocysts present; otherwise similar to preceding stage

Antenna similar to preceding stage.

Mandibles (Fig. 39) with incisor process curved, bearing 3 strong teeth; molar process stout, subquadrate, bearing 7 strong teeth and several denticles.

Maxillule (Fig. 40) with coxal endite bearing several, simple, weakly plumose, serrate, setae terminally and subterminally; basial endite bearing 2 simple setae proximally plus 1 plumose seta subterminally on inner lateral margin, and several spines plus serrate setae on distal margin; endopod bilobed, lower lobe with small, curved spine.

Maxilla (Fig. 41) with protopod bearing 5-6 and 7-8 simple setae on lower and upper lobes, respectively; endopod bearing 2-3 simple setae proximally on outer lateral margin; simple seta present on anterolateral surface of scaphognatite.
Maxilliped 1 (Fig. 42). Protopod with coxal endite bearing 2-3 simple setae plus 3-4 long, plumose seta; basial endite with several, simple and serrate, short setae along distal margin, 2 simple plus 2 plumose setae subdistally on outer lateral margin, and 3 median setae on the ventral surface (not illustrated).

Maxilliped 2 (Fig. 43). Endopod 4-segmented; penultimate segment with 3 weakly plumose setae subdistally on outer lateral margin, 3 weakly plumose setae on ventral surface of distal margin (not illustrated); last segment with 6 simple plus 1 weakly plumose setae subdistally on dorsal surface, and several short, simple and serrated, setae along distal margin.

Maxilliped 3 (Fig. 44). Endopod 4-segmented, with segmentation between penultimate and last segment distinct. Otherwise similar to preceding stage.

Pereiopods 1-2 with chela well developed, fully functional. Chela of pereiopod 1 (Fig. 45) with palm bearing 3 short, serrated plus 1 long, simple setae proximally on the lower margin, 2 simple setae distally on the upper margin; fixed and movable fingers tipped with tuft of simple setae, sets of simple plus serrated setae present medially on both fingers. Chela of pereiopod 2 (Fig. 46) with lower margin of palm smooth; upper margin with 1 median simple setae, 1 short plus 1 long simple setae distally; both fingers with sets of setae and tipped with tuft of simple setae. Pereiopod 2 longest, approximately 1.7 times the length of pereiopod 1.

Pereiopods 3-5 similar to preceding stages.

Pleon (Fig. 36) with pleonites I-V bearing 0, 0, 2, 2, 3-5 setae on ventro-lateral margins.

Pleopods 1-5 with increasing number of marginal setae on their endopods and exopods. Pleopod 1 with endopod bearing 1 plumose setae apically.

Uropods (Fig. 47). Endopod fully developed, with several short, weakly plumose setae scattered along outer lateral margin and dorsal surface, 16-18 long, plumose setae along distal and inner lateral margins. Otherwise similar to preceding stage, except for exopod with number of setae slightly increased.

Telson (Fig. 47) subrectangular, narrower on its distal third; distal margin strongly convex, bearing $8+8$ plumose setae, 1 pair of long spine on disto-lateral corner, 2 pairs of small spines, distally and subdistally, on lateral margins, 1 pair of dorsal-lateral spines approximately on the distal third of telsonic length. 


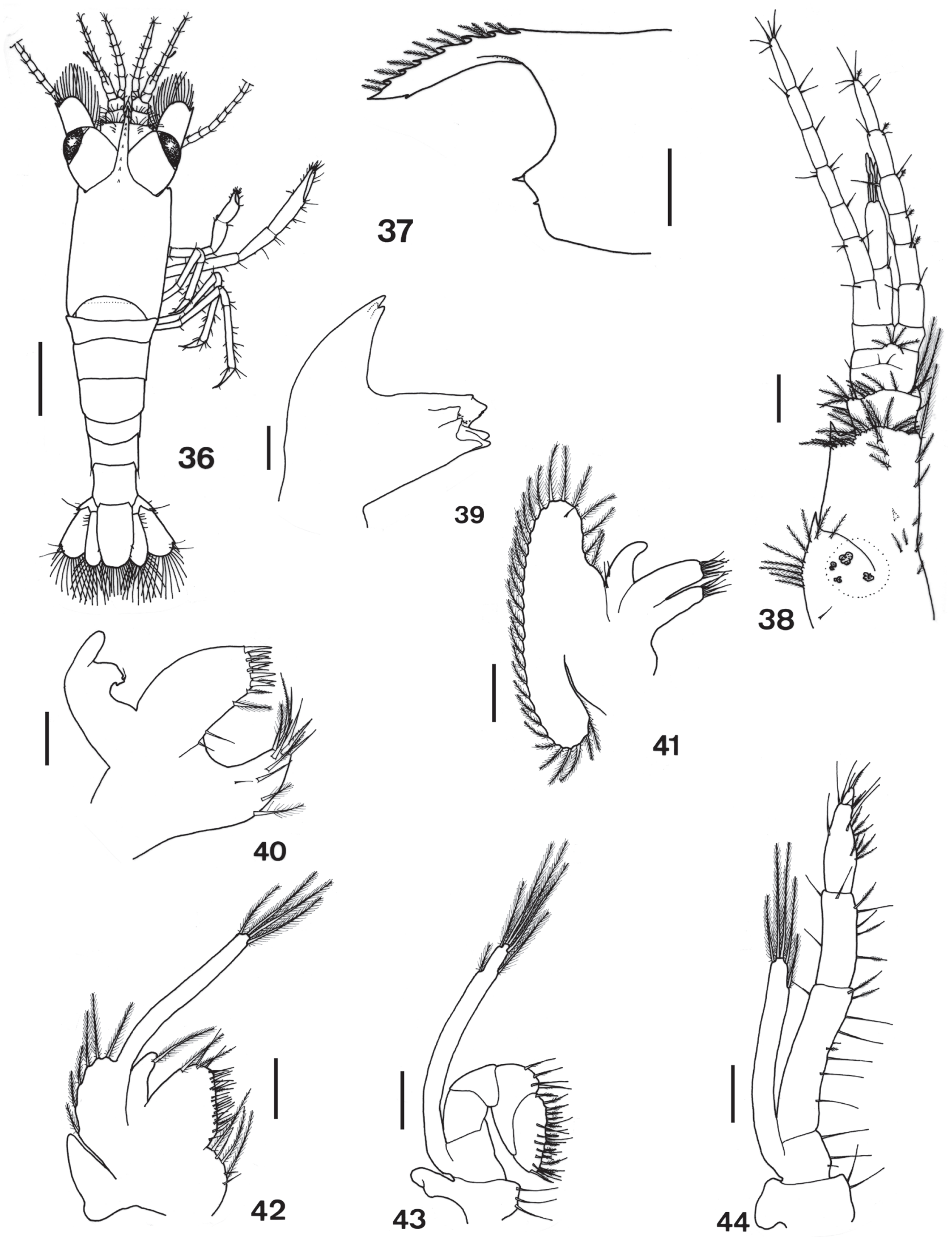

Figures 36-44. Macrobrachium inpa Kensley and Walker, 1982, first juvenile stage. 36, Dorsal view (left thoracic appendages not represented); 37, Lateral view of the anterior region of the carapace; 38, Antennule; 39, Mandible; 40, Maxillule; 41, Maxilla; 42, Maxilliped 1; 43, Maxilliped 2; 44, Maxilliped 3. (Scale bars: $36=1 \mathrm{~mm} ; 37=0.5 \mathrm{~mm} ; 38,41-44=0.2 \mathrm{~mm} ; 39,40=0.1 \mathrm{~mm}$ ). 

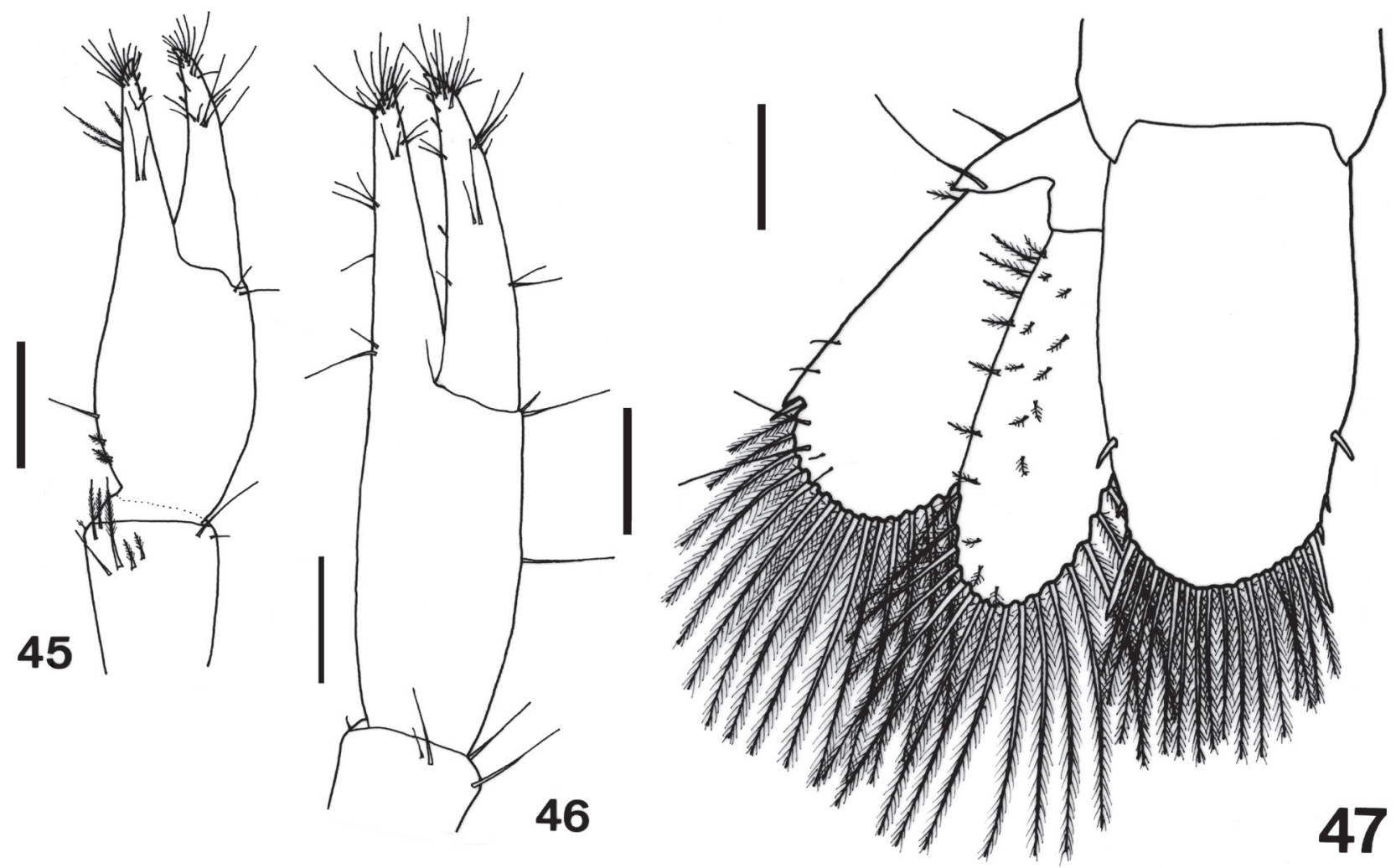

Figures 45-47. Macrobrachium inpa Kensley and Walker, 1982, first juvenile stage. 45, Pereiopod 1 (only chela and distal portion of carpus); 46, Pereiopod 2 (only chela and distal portion of carpus); 47, Left uropod and telson. (Scale bars: 45-47 = $0.2 \mathrm{~mm}$ ).

\section{Discussion}

The relatively short duration (10-11 days) of the larval period, the benthic behavior, and the advanced morphological features exhibited by lecithotropic larvae on hatching characterize Macrobrachium inpa as a species with an abbreviated type of larval development according to the categorizations made by Gore (1985), Rabalais and Gore (1985), Anger (2001), Jalihal et al. (1993), and by Guerao and Cuesta (2014). Gore (1985) and Rabalais and Gore (1985) further subdivided this category into "direct development" and "advanced development". Macrobrachium inpa can be categorized as pertaining to advanced type of development. In the much subdivided classification proposed by Jalihal et al. (1993), M. inpa can be included in the Type II-Ai-c. Although the newly-hatched larvae are not freeswimming and bear some quite advanced morphologic characters (antenna with several marginal plumose seta on scaphocerite and long, multi-articulated flagellum; fully developed, functional walking legs and pleopods; no trace of exopods in the pereiopods), they also exhibit some typical larval features (such as sessile eyes, unsegmented antennule, mostly rudimentary mouthparts - at least for the structures involved in feeding activities -, nonfunctional chelipeds, and absence of free uropods and spatulated telson). These structures gradually improve their morphology towards the basic adult shape, which is attained at the third molt. Additionally, in spite of the low number of observations, the developmental sequence can be considered as regular, both in terms of duration and number of ecdysis.

Several names for larval forms have been used in the decapod larval development literature. Williamson (1982), Gore (1985), Anger (2001), and Guerao and Cuesta (2014) thoroughly discussed this issue and offered slightly different definitions. They all used the criteria of functional morphology (particularly the situation of the locomotory appendages) to denominate the larval forms. According to the terminology proposed by Anger (2001), I considered M. inpa as exhibiting a decapodid type of larval form because the newly-hatched larvae use their already fully formed and functional walking legs (pereiopods 3-5) and pleopods as the main structures for displacement and propulsion. The features of larval stages given by 
Guerao and Cuesta (2014) are somewhat too general to adequately define the larval stages of $M$. inpa, which is apparently among the many exceptions as cautioned by the authors.

The number and size of the eggs carried by the females of $M$. inpa verified in the present study are very similar to those found by Gualberto et al. (2012). In their study, 18 similarly sized ovigerous females (25.8-32.8 $\mathrm{mm}$ versus $27.0 \pm 1.64 \mathrm{~mm}$ in this study) carried 6-21 eggs (versus 8-19) with a size of $2.46 \mathrm{X}$ $1.70 \mathrm{~mm}$ (versus $2.39 \mathrm{X} 1.67 \mathrm{~mm}$ ). These similarities can be explained by the population's taxonomic identity or because the populations in both studies come from nearby locations in the same geographical area.

The molts during the larval phase of $M$. inpa do not imply significant changes in size and morphology (probably also in biomass, but this was not measured in this study), thus corroborating the typical larval trait of the decapodids seen in caridean shrimps as mentioned by Anger (2001). Similarly, transition from decapodid to the juvenile phases in $M$. inpa is very gradual as most of the morphological structures are already fully developed at the third decapodid stage. Only those structures involved primarily in feeding activities (mandibles, maxillule, inner parts of maxilla and maxillipeds, and chelae of pereipods 1 and 2) still bear incipient features in the third larval stage, as the larvae at this stage are still lecithotropic, but become fully developed and functional after the third molt, thus marking the end of the very abbreviated larval period.

The abbreviated development is the common type of larval development found in the so-called "continental" group of the caridean shrimps from the Amazon River basin, i.e., those species that have penetrated the interior of the continent and became independent of the estuaries (Rodríguez, 1981). Except for Macrobrachium amazonicum (Heller, 1862), that has regular development (as defined in Gore, 1985) with 10-11 stages of free-swimming zoea (Magalhães, 1985), all other species with documented larval development exhibit both types of abbreviated development. Some can be considered direct developers as they hatch as a nearly complete imago of the adult which needs only one molt to complete the telson morphology and mouthparts; such species are Euryrhynchus amazoniensis Tiefenbacher, 1978, Euryrhynchus burchelli Calman, 1907 and Euryrhynchus wrzesniowski
Miers, 1877 (see Magalhães, 1988a), and Palaemon mercedae (Pereira, 1986) (see Magalhães, 1988b). The other Amazonian species can be categorized as having advanced development. Although their larval period is restricted to three larval stages, some differences can be found within this group regarding the more or less advanced morphology shown by the larvae on hatching (for the descriptions of the larval development of Palaemon ivonicus, Pseudopalaemon chryseus, Macrobrachium nattereri, Pseudopalaemon amazonensis, and Macrobrachium jelskii (Miers) see, respectively, Magalhães (1986), Magalhães (1986/87), Magalhães (1989), Magalhães and Medeiros (1998), and Magalhães (2000)). Other South American continental species of Macrobrachium that also have such type of development are: Macrobrachium potiuna (Müller, 1880) (see Müller, 1892 and Graça-Melo and Brossi-Garcia, 1999, as Macrobrachium petronioi Melo, Lobão and Fernandes, 1986 is a junior synonym of $M$. potiuna, according to Pileggi and Mantelatto, 2012); Macrobrachium brasiliense (see Vega-Pérez, 1984); Macrobrachium ferreirai Kensley and Walker, 1982 (see Magalhães and Walker, 1988); Macrobrachium iheringi (Ortman, 1897) (see Bueno and Rodrigues, 1995); and Macrobrachium reyesi Pereira, 1986 (see Pereira and García, 1995).

When compared to other Amazonian palaemonid shrimps, the advanced larval development of $M$. inpa is more similar to that exhibited by Pseudopalaemon chryseus, Ps. amazonensis, and M. ferreirai. The larvae of those species also hatch as decapodid whose locomotion and propulsion are provided mainly by the fully developed, functional walking legs (pereiopods 3-5) and pleopods (Magalhães, 1986/87; Magalhães and Medeiros, 1998; C. Magalhães, unpubl. data). The other Amazonian species of Macrobrachium for which the abbreviated larval development have been described do not show a degree of abbreviation as high as that of $M$. inpa. The main differences among them are that in the first larval stage of $M$. nattereri (see Magalhães, 1989) the distal flagella of the antennule is partially fused and not separated from the peduncle (vs. flagella individualized and clearly separated from the peduncle in $M$. inpa); the antenna has a partially developed scaphocerite, with only a few plumose setae along the distal margin, and an unsegmented flagellum, only twice as long as the scale (vs. fully developed 
scaphocerite and a long, multisegmented flagellum in $M$. inpa); pereiopods 3-5 are nonfunctional buds (vs. fully developed, functional in M. inpa); all pair of pleopods are smooth, not functional buds (vs. fully developed, setaceous and functional in $M$. inpa); the telson is similar in both species, but it is less setaceous in $M$. nattereri (7+7 marginal plumose setae) than in $M$. inpa $(12+12)$. Other noteworthy differences in the second larval stage can be found in the antenna (scaphocerite still partially developed as in the first stage, in $M$. nattereri), pleopods (as buds a little more developed, but still not setaceous, in $M$. nattereri), and telson (outline of lateral margins clearly discontinued due to exopodal buds being partially protruded in $M$. nattereri vs. a continuous outline in $M$. inpa); in the third stage the larvae of both species are, in general, very similar.

The differences are even greater when the larval development of $M$. inpa is compared to that of $M$. jelskii (see Magalhães, 2000), which has a little less developed larval form on hatching due to features such as: antenna with a segmented flagellum only about 1.5 times longer than the scaphocerite; maxilla with outer margin of scaphognathite devoid of plumose setae; pereiopods 1-2 as biramous, chelate buds, with the exopod as a smooth, incipient bud; pereiopods 3-5 as uniramous buds; pleopods as biramous, smooth buds; and telson with 9+9 plumose setae. In the second and third larval stages, the cheliped buds still keep the exopod, but bearing distal plumose setae, and the pleopods are still glabrous, with incipient appendix interna. Moreover, the uropods are freed at the third stage, but the endopod is still rudimentary. Therefore, the biramous chelipeds and the underdeveloped, not fully functional pleopods throughout the larval period seem to be the most remarkable differences between the larval developments of these two species.

Unfortunately, comparison between the larval development of $M$. inpa and $M$. ferreirai cannot be properly made because Magalhães and Walker (1988) offered very brief information on the first larval stage of the latter species, mostly about the behavior of the newly-hatched larvae. However, their larval development must be very similar since the first larval stage of $M$. ferreirai also bears fully developed, functional walking legs and pleopods (C. Magalhães, unpubl. data). It would also be interesting to compare the larval development of $M$. inpa and Macrobrachium cortezi Rodríguez, 1982. Rodríguez (1982) described the latter species from the upper Orinoco River basin and it is suspected that it could be a senior synonym of M. inpa (G. Pereira, pers. comm.).

\section{ACKNOWLEDGEMENTS}

This paper is dedicated to Prof. Dr. Nilton José Hebling in appreciation for his remarkable role in the development of the Brazilian carcinology, as well as in gratitude for his support and encouragement during my early studies about the larval development of the Amazonian shrimps. I thank Dr. Klaus Anger and two anonymous reviewers for constructive comments on the manuscript, the Conselho Nacional de Desenvolvimento Científico e Tecnológico - CNPq for an ongoing research grant (proc. 303837/2012-8), Dr.J. A. Cuesta, for kindly sending a copy of his paper, and Ms. Colleen L. Flanagan for the linguistic revision of the English text.

\section{References}

Alvarez, F.; Villalobos, J.L. and Robles, R. 2002. Abbreviated larval development of Macrobrachium tuxtlaense Villalobos and Alvarez, 1999, reared in the laboratory. Crustaceana, 75(5): 717-730.

Anger, K. 2001. The Biology of Decapod Crustacean Larvae. Lisse, A.A. Balkema, 419p.

Bueno, S.L. de S. and Rodrigues, S. de A. 1995. Abbreviated larval development of the freshwater prawn, Macrobrachium iheringi (Ortmann, 1897) (Decapoda, Palaemonidae), reared in the laboratory. Crustaceana, 68(6): 665-685.

Gore, R.H. 1985. Molting and growth in decapod larvae. p. 1-65. In: A.M. Wenner (ed), Larval Growth. Crustacean Issues, vol. 2. Rotterdam, A.A. Balkema.

Graça Melo, S. and Brossi-Garcia, A.L. 1999. Postembryonic development of Macrobrachium petronioi (Caridea: Palaemonidae) in the laboratory. Journal of Crustacean Biology, 19(3): 622-642.

Gualberto, T.L.; Almeida, L.O. and Menin, M. 2012. Population structure, fecundity and ecological aspects of freshwater shrimp species (Decapoda, Palaemonidae) of an urban forest fragment in Central Amazonia, Brazil. Crustaceana, 85(10): 1205-1219.

Guerao, G. and Cuesta, J.A. 2014. Caridea. p. 250-255. In: J.W. Martin; J. Olesen and J.T. Hoeg (eds), Atlas of Crustacean Larvae. Baltimore, Johns Hopkins University Press.

Jalihal, D.R.; Sankolli, K.N. and Shenoy, S. 1993. Evolution of larval developmental patterns and the process of freshwaterization in the prawn genus Macrobrachium Bate, 1868 (Decapoda, Palaemonidae). Crustaceana, 65(3): 365-376. 
Kensley, B. and Walker, I. 1982. Palaemonid shrimps from the Amazon basin, Brazil (Crustacea, Decapoda, Natantia). Smithsonian Contribution to Zoology, 362: 1-28.

Magalhães, C. 1985. Desenvolvimento larval obtido em laboratório de palaemonídeos da Região Amazônica. I. Macrobrachium amazonicum (Heller, 1862) (Crustacea, Decapoda). Amazoniana, 9(2): 247-274.

Magalhães, C. 1986. The larval development of palaemonid shrimps from the Amazon Region reared in the laboratory. IV. The abbreviated development of Palaemonetes ivonicus Holthuis, 1950 (Crustacea: Decapoda). Amazoniana, 10(1): 67-78.

Magalhães, C. 1986/87. The larval development of palaemonid shrimps from the Amazon Region reared in the laboratory. V. The abbreviated development of Pseudopalaemon chryseus Kensley and Walker, 1982 (Crustacea: Decapoda: Palaemonidae). Acta Amazonica, 16/17: 95-108.

Magalhães, C. 1988a. The larval development of palaemonid shrimps from the Amazon Region reared in the laboratory. II. Extremely abbreviated larval development in Euryrhynchus Miers, 1877 (Decapoda, Euryrhynchinae). Crustaceana, 55(1): 39-52.

Magalhães, C. 1988b. The larval development of palaemonid shrimps from the Amazon Region reared in the laboratory. III. Extremely abbreviated larval development of Palaemonetes (Palaemonetes) mercedae Pereira, 1986 (Crustacea, Decapoda). Studies of Neotropical Fauna and Environment, 23(1): 1-8.

Magalhães, C. 1989. The larval development of palaemonid shrimps from the Amazon Region reared in the laboratory. VI. Abbreviated development of Macrobrachium nattereri (Heller, 1862) (Crustacea: Decapoda). Amazoniana, 10(4): 379-392.

Magalhães, C. 2000. Abbreviated larval development of Macrobrachium jelskii (Miers, 1877) (Crustacea: Decapoda: Palaemonidae) from the Rio Solimões floodplain, Brazil, reared in the laboratory. Nauplius, 8(1): 1-14.

Magalhães, C. 2009. Crustáceos Decápodos. p. 35-40. In: C.R.V. Fonseca; C. Magalhães; J.A. Rafael and E. Franklin (Orgs), A Fauna de Artrópodes da Reserva Florestal Ducke. Estado Atual do Conhecimento Taxonômico e Biológico. Manaus, INPA.

Magalhães, C. and Medeiros, N. 1998. The larval development of palaemonid shrimps from the Amazon Region reared in the laboratory. VI. Abbreviated development of Pseudopalaemon amazonensis Ramos-Porto, 1979 (Crustacea: Decapoda: Caridea). Acta Amazonica, 28(4): 433-448.

Magalhães, C. and Pereira, G. 2007. Assessment of the decapod crustacean diversity in the Guayana Shield region aiming at conservation decisions. Biota Neotropica, 7(2): 111-124.
Magalhães, C. and Walker, I. 1988. Larval development and ecological distribution of Central Amazonian palaemonid shrimps (Decapoda: Caridea). Crustaceana, 55(3): 279-292.

Müller, F. 1892. O camarão preto, Palaemon potiuna. Segunda parte: A metamorphose dos filhos. Archivos do Museu Nacional, Rio de Janeiro, 8: 192-206, pls. 12-13.

Pereira S., G.A. and García P., J.V. 1995. Larval development of Macrobrachium reyesi Pereira (Decapoda: Palaemonidae), with a discussion on the origin of abbreviated development in palaemonids. Journal of Crustacean Biology, 15(1): 117-133.

Pileggi, L.G. and Mantelatto, F.L. 2010. Molecular phylogeny of the freshwater prawn genus Macrobrachium (Decapoda, Palaemonidae), with emphasis on the relationships among selected American species. Invertebrate Systematics, 24(2): 194-208.

Pileggi, L.G. and Mantelatto, F.L. 2012. Taxonomic revision of doubtful Brazilian freshwater shrimp species of genus Macrobrachium (Decapoda, Palaemonidae). Iheringia, Série Zoologia, 102(4): 426-437.

Rabalais, N.N. and Gore, R.H. 1985. Abbreviated development in Decapods. p. 67-126. In: A.M. Wenner (ed), Larval Growth. Crustacean Issues, vol. 2. Rotterdam, A.A. Balkema.

Rodríguez, G. 1981. Decapoda. p. 41-51. In: S.H. Hurlbert; G. Rodríguez and N.D. Santos (eds), Aquatic Biota of Tropical South America, Part 1: Arthropoda. San Diego, San Diego State University.

Rodríguez, G. 1982. Fresh-water shrimps (Crustacea, Decapoda, Natantia) of the Orinoco basin and the Venezuelan Guayana. Journal of Crustacean Biology, 2(3): 378-391.

Signoret P.B., G.; Ortega M., A.L. and Brailovsky S. D. 2000. Partially abbreviated larval development in an undescribed freshwater palaemonid prawn of the genus Macrobrachium from Chiapas, Mexico. Crustaceana, 73(3): 273-282.

Vega-Perez, L.A. 1984. Desenvolvimento larval de Macrobrachium heterochirus (Wiegmann, 1836), Macrobrachium amazonicum (Heller, 1862) e Macrobrachium brasiliense (Heller, 1862) (Crustacea, Decapoda, Palaemonidae), em laboratório. Universidade de São Paulo, São Paulo, Brazil, Doctor Dissertation. 277p. [Unpublished].

Walker, I. and Ferreira, M.J.N. 1985. On the population dynamics and ecology of the shrimp species (Crustacea, Decapoda, Natantia) in Central Amazonian River Taruma-Mirim. Oecologia, 66(2): 264-270.

Williamson, D.I. 1982. Larval morphology and diversity. p. 43-110. In: L.G. Abele (ed), Embryology, Morphology and Genetics. The Biology of Crustacea, vol. 2. New York, Academic Press. 